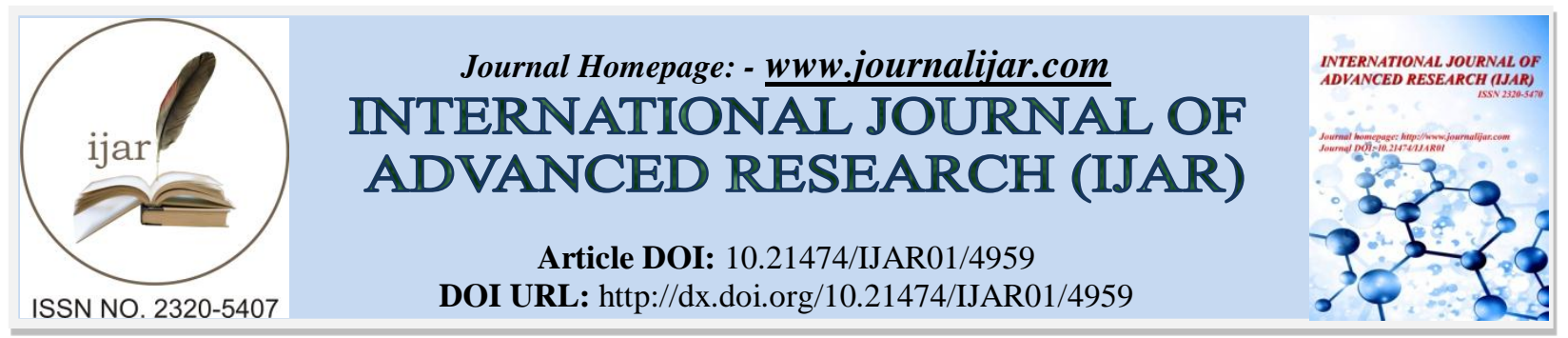

RESEARCH ARTICLE

\title{
SINGLE CELL PROTEIN PRODUCTION USING VARIOUS MICROBIAL MASS: A REVIEW.
}

\author{
Anamika Malav ${ }^{1}$ and *Prahlad Dube \\ 1. Department of Microbiology, C P University, Kota. \\ 2. Head, Department of Zoology, Govt College, Kota.
}

\section{Manuscript Info}

Manuscript History

Received: 26 May 2017

Final Accepted: 28 June 2017

Published: July 2017

Key words:-

Single cell protein, Algae, Bacteria,

Fungi, Yeast, Soya, agro based-

industrial waste

\section{Abstract}

Malnutrition is a big problem in India and other parts of the world. We can use various microbes for production of single cell protein to solve malnutrition problem. The scientists are trying this problem by using various microbes such as algae, bacteria, fungi and yeast. In the present paper, literature is surveyed and critically examined regarding SCP production.

Copy Right, IJAR, 2017,. All rights reserved.

\section{Introduction:-}

One of the alternate and unconventional source of protein is the single cell protein (SCP), which is the dried microbial mass a total protein extracted from cultivation microbial biomass (Algae, bacteria, fungi, and yeast) on various substrates. Yeast is one of the best micro-organism for production of single cell protein because of its high nutritional quality and can be put side by side with animal proteins (Adedayo et al., 2011). Yeasts have a balance proportion of amino acids, B-complex vitamins (Amata, 2013) and also having probiotic properties therefore more suitable for poultry feed. Yeasts are eukaryotic unicellular micro fungi that are widely distributed in the nature. Yeast is rich in protein, vitamins and minerals (Barbara et al., 2011) therefore it can be used effectively as an alternate protein source in livestock feeds. Yeast has already been used in animals' diet to compensate amino acid and vitamins deficiencies and can be used to replace Soya bean meal in poultry ration (Gohl, 1981). Yeast and soybean have more or less similar essential amino acid composition and may be a good source to cope up the shortage of protein supply. Yeast single cell protein is cheaper dietary protein source, as it can be produced from various substrates (molasses, cellulose, starch etc) on large scale in industry.

Using alternative low price protein sources in the diet could be a suitable option for reducing the cost. Several microbes like algae, bacteria, yeast and fungus act as protein producers (Azam et al., 2014) and can be used in the diet of poultry. Of these microbes, yeast is mainly used in single cell protein (SCP) production. This is because of its rapid growth rate and high efficiency to convert carbon source into protein (Glazer and Nikaido, 2017). Yeast and yeast products produced from agro-industrial by products are rich in protein contents (Silva et al., 2009).. Similarly, yeast sludge (product of distillery industry) contains crude protein (27-29\%; Ali, 2004) and can be used in diet (Verma and Sundar, 1988). It also contains some essential amino acids which are necessary for proper diet (Rameshwari and trub. It is considered as a waste product and it is difficult to manage and dispose it (Bustamante $e t$ al., 2008). About 1,300 tons distillery yeast sludge (DYS) is produced and wasted annually in Pakistan (Khan, 2001). 
New advance in biotechnological techniques have made potentially effective and economic use of wastes into valuable products including single cell protein (SCP). Increasing concern about pollution caused by the agri-wastes has also stimulated the interest for conversion of these wastes into commercially valuable products. One of the most promising ways is to use such wastes as substrates for the cultivation of yeast for the production of protein rich single cell biomass. The agri-wastes contain cellulose, lignin, and hemicelluloses and can be converted into fermentable sugars which then serve as substrate for growth of different enzymes producing microbes. The biomass of bacteria and yeast is termed as single cell protein (SCP) which is an excellent protein source and might be used as a promising alternative to other conventional protein sources (Kurbanoglu and Algur, 2001; Khan and Dahot, 2010; Qazi et al., 2012). The bioconversion of wastes into SCP is a cheaper and economically feasible way to overcome the protein scarcity (Anupma and Ravindra, 2000). Various fruit wastes being particularly rich in sugars and Polysaccharides represent very appealing substrates for cultivating microbial (bacteria and yeast) biomass. Rapid growth rate, high protein content and their ability to utilize inexpensive feed stocks as carbon and energy sources for growth have made micro organisms' prime candidates for animal as well as animal protein supplements. Yeast biomass is easy to harvest due to larger cell size, high protein content, flocculating ability and less nucleic acid contents as compared to bacterial cells (Wolf et al., 2003). The SCP biomass produced may serve as an ideal supplement for aqua feeds. (Khan and Dahot, 2010). Microbes have $46 \%$ of crude protein content processing large quantities of essential amino acids. (Rao et al., 2003). A wide variety of agri industrial wastes such as peels of orange, mangoes and rice straw, corn straw and sugarcane bagasse have been investigated for SCP production (Nigam et al., 2000; Zhao et al., 2010a). These wastes are present abundantly in nature and may serve as a sole carbon and nitrogen source for the production of SCP by micro-organisms. The agro industrial wastes including straw, bagasse, molasses. Fruit and vegetables peels are locally produced in higher amounts and increase the pollution level to a significant level. Thus these wastes can be utilized for SCP, thereby causing a reduction in pollution level as well as producing SCP biomass. Hence bioconversion of wastes into SCP is a cheaper and economically feasible way to overcome the protein scarcity.

Micro-organisms can utilize waste materials that cause pollution problem and also sanitary hazards. The use of wastes would help in controlling pollution and also in solving waste disposal problem to some extent. Single cell protein (SCP) production has the potential for feeding the ever increasing world population at cheaper rates (Baldasso et al., 2011). The protein comes from a number of vegetables, cereals and fruits, often not affordable by a common man and therefore microbial proteins can be an alternative source to feed economically down communities in the world in general and India in particular. In other words proteins are the essence of life processes and are important for proper growth and development of all the living beings. Its deficiency may lead to a number of health disorders. The term single cell protein refers to dead, dry cells of micro-organisms such as yeast, bacteria, fungi and algae which grow on different carbon sources (Anupma and Ravindra, 2000). Single cell protein typically refers to source of mixed protein extracted from pure or mixed culture of algae, yeast, fungi or bacteria (Khan et al., 2010; Ware, 1977). In present investigation, a simple process for utilizing whey protein and converting lactose to SCP in order to obtain product which enhance the biological value of micro-organism Bacillus subtilis. This bacterium is screened for its growth and SCP production using whey as a substrate. Whey has the importance in dairy industry due to its nutritional value. It is produced in large amount as the by-product of cheese or casein production. The utilization of whey as protein substrate from bacteria was found to be more efficient. The aim of the present study was to evaluate the liquid whey as a potential substrate for Single Cell Protein production from Bacillus subtilis NCIM 2010.

\section{Sources Of Single Cell Proteins:-}

1. Certain microbes which have high protein content are considered to be very much beneficial for the production of SCP. Such prepared biomass can be utilized for the human consumption as protein rich food. Generally, these microbes can grow in an industrial bioreactor with the utilization of common wastes such as sewage, animal excreta, agricultural wastes, petroleum wastes, crude oil waste, paper and textile industry wastes, saw mill wastes, starchy waste from potato industry, beverage industrial wastes and distilleries waste.

2. The production of SCP from various microbes, particularly from fungi and bacteria has received considerable attention, in contrast, only a few studies have dealt with the feasibility of using SCP from micro algae.

3. Comprehensive analysis and nutritional studies have demonstrated that these algal proteins are of high quality and comparable to conventional vegetable proteins. However, due to high production costs as well as technical difficulties to incorporate the algal material into palatable food preparations, the propagation of algal proteins is still in its infancy. 


\section{Production Of Single Cell Protein In Yeast:-}

SCP produced using yeast is a high nutrient feed substitute (Burgents et al, 2004). Among these most popular are yeast species Candida (Bozakouk, 2002), Hansenula, Pitchia, Torulopsis and Saccharomyces. The production of single cell protein using Saccharomyces cerevisiae grown on various fruit waste is also reported (Tanveer, 2010). The typical oily yeasts genera include Yarrowia, Candida, Rhodotorula, Rhodosporidium, Cryptococcus, Trichosporon and Lipomyces. Cucumber and orange peels were evaluated for the production of single cell protein using Saccharomyces cerevisiae by submerged fermentation (Sengupta et al., 2006). No mention of SCP production using yeast on soya agrowaste was found in literature.

\section{Production Of Single Cell Protein In Algae:-}

Since ancient times, Spirulina was cultivated by people near Lake Chad in Africa and the Aztecs near Texcoco in Mexico. They used it as a food after drying it. Spirulina is the most widely used algae so much that even astronauts take it to space during their space travel. Similarly, biomass obtained from Chlorella and Senedessmus has been harvested and used as source of food by tribal communities in certain parts of the world. Alga is used as a food in many different ways and its advantages include simple cultivation, effective utilization of solar energy, faster growth and high protein content. The algae Spirulina has been considered for use as a supplementary protein (Raja et al., 2008). It is a blue green algae having strong antioxidant activity and provokes a free radical scavenging enzyme system.

A diet enriched with Spirulina and other nutraceuticals may help protect the stem/progenitor cells. Spirulina maxima prevent fatty liver development induced by carbon tetrachloride $\left(\mathrm{CCl}_{4}\right)$. It is concluded that the use of Spirulina should be encouraged in patients suffering from malnutrition, immune suppression, hepatic and neural compromise, etc. although further investigations on the antiviral effects of this alga and its clinical implications are strongly needed. Single cell protein (SCP) production by five strains of Chlorella species (M109, M121, M122, M138, and M150), isolated from different habitats, and was studied under the influence of eight environmental factors (Mahasneh, 2005).

\section{Production Of Single Cell Protein In Fungi:-}

Many fungal species are used as a source of protein rich food (Bhalla et al, 2007). Many other filamentous species are also used as source of single cell protein. In 1973, in second international conference convened at MIT, it was reported that Actinomycetes and filamentous fungi produced protein from various substrates. During the World War II, trials were made to utilize the cultures of Fusarium and Rhizopus (Yousuf, 2012) grown in fermentation as a source of protein food. The inoculums of Aspergillus oryzae (Anupama and Ravindra, 2000) or Rhizopus arrhizus were selected because of their non-toxic nature. Saprophytic fungi grow on complex organic compounds and convert them into simple structures. High amount of fungal biomass is produced as a result of growth. Mycelia yield vary greatly which depends upon organisms and substrates.

There are some species of moulds, for example, Aspergillus niger (Yabaya and Ado, 2008). A. fumigates, Fusarium graminearum which are very dangerous to human, therefore, such fungi, must not be used or toxicological evaluations should be done before recommending using as SCP. Very recently, SCP technology is using fungal species for bioconversion of lignocellulosic wastes (Lenihan et al, 2010). The filamentous fungi that have been used include Chaetomium Celluloliticum, Fusarium Graminearum (Zubi, 2005), Aspergillus fumigates, A. niger, A.oryzae, Cephalosporium cichorniae, Penicillum cyclopium, Rhizopuschinesis, Scytalidum aciduphlium, Tricoderma viridae, and Tricoderma alba Paecilomyces varioti (Jaganmohan et al., 2013).

\section{Production Of Single Cell Protein In Bacteria:-}

Characteristics that make bacteria suitable for SCP production include rapid growth of bacteria, short generation time and can double their cell mass in 20 minutes to 2 hours. They are also capable of growing on a variety of raw materials that range from carbohydrates such as starch and sugars to gaseous and liquid hydrocarbons which include methane and petroleum fractions (Bamberg, 2000) to petrochemicals such as methanol and ethanol, nitrogen sources which are useful for bacterial growth include ammonia, ammonium salts, urea, nitrates, and the organic nitrogen in wastes, also it is suggested to add mineral nutrient supplement to the bacterial culture medium to fulfil deficiency of nutrients that may be absent in natural waters in concentration sufficient to support growth. Potential phototrophic bacterial strains are recommended for single cell protein production. Some researchers also suggest use of methanotrophic and other bacterial species for single cell protein production (Arora et al., 1991). Generation time of 
Methylophilusis about 2 hours is used in animal feed and in general produces a more favourable protein composition than yeast or fungi.

Therefore, the large quantities of single cell protein animal feed can be produced using bacteria like Brevibacterium (Adedayo et al., 2011) Methylophilus methylitropous, Acromobacter delvaevate, Acinetobacter calcoacenticus, Aeromonas hydrophilla, Bacillus megaterium, Bacillus subtilis (Gomashe et al., 2014), Lactobacillus species, Cellulomonas species, Methylomonas methylotrophus ( Piper, 2004), Pseudomonas fluorescens, Rhodopseudomonas capsulate, Flavobacterium species, Thermomonospora fusca (Dhanasekaran et al., 2011).

\section{Conclusion:-}

It is clear from above discussion and critical review of available literature that various microbes could be used for production of single cell protein to solve protein malnutrition problem in India and other parts of the world. Various studies have described production of SCP using many waste products and microbial organism and presented their advantages and disadvantages. Every method of production is suitable for particular need. In this we found that soya agro-industry waste using yeast as microbe is promising field and much work can be done in this field.

\section{References:-}

1. Adedayo, M.R., Ajiboye, E.A., Akintunde, J.K., Odaibo, A. 2011. SCP: As nutritional Enhancer. J. Microbiol., 2(5): 396-409.

2. Amata, I.A., 2013. Yeast single cell protein: Characteristics and metabolism. Int. J. appl. Biol. Pharma. Tech., 4:158-170.

3. Anupama, Ravindra, 2000. Value added Food: single cell protein. Biotechnol. Adv. J. Microbiol., 18: 459-479.

4. Arora, D., Mukerji, K., Marth, E. 1991. Single cell protein in Hand book of applied mycology. J.A m. Sci., 18: 499-539.

5. Bamberg, .J. H. 2000. British Petroleum and Global Oil. 1950-197: The Challenge of Nationalism, Cambridge University Press. 3, 426-428.

6. Barbara, R., Canela, A.A.L., Mora, M., Motta, W.F., Lezcano, P. and Euler, A.C., 2011. Mineral composition of torula yeast (Candida utilis), grown on distiller's vinasse. Cub. J. agri. Sci., 45: 151-154.

7. Baldasso C, Barros TC, Tessaro IC (2011) Concentration and purification of whey proteins by ultrafiltration. Desalination, 278: 381-38.

8. Bhalla, T.C., Sharma, N.N., Sharma, M.2007. Production of metabolites, industrial enzymes, amino acids, organic acids, antibiotics, vitamins and single cell proteins. J. Environ. Issues, 6: 34-78.

9. Bozakouk, A.H. 2002. Acid hydrolysis of Phragmites austral: is powder for production of single cell protein by Candida utilis. J. Res., 98: 876-897.

10. Burgents, J.E., Burnett, K.G., Burnett, L.E. 2004. Disease resistance of pacific white shrimp, Litopenaeus vannamei, following the dietary administration of a yeast culture food supplement, Aquacult. J. Microbiol., 231: $1-8$.

11. Bustammante, M.A., Moral, R., Paredes, C., Espinosa, A.P., Caselles, J.M. and Murica, M.D.P. (2008). Agrochemical characterization of the solid by products and residue from the winery and distillery industry. Waste Manag. 28: 372-380.

12. Dhanasekaran, D., Lawanya, S.S., Saha, N.T., Panneerselvam, A. 2011. Production of single cell protein from pineapple waste using yeast. Innovat. Roman. Food Biotechnol., 8: 26-32.

13. Gaberiel, A., Ntuli, V., James, D. 2014. CICactus pear biomass, a potential lignocellulose raw material for Single Cell Protein production (SCP). Int. J. Curr. Microbiol. Appl. Sci., 3(7): 171-197.

14. Gomashe, A.V, Pounikar, M.A., Gulhane, P.A. 2014. Liquid whey: a potential substrate for single cell protein production from Bacillus subtilis NCIM 2010. Int. J. Life Sci., 2(2): 119-123.

15. Jaganmohan, P., Purushottam, B., Prasad, S.V. 2013. Production of SCP with Aspergillus terrus using Solid State fermentation. Eur.J.Biol. Sci., 5(2): 38-45.

16. Khan, M.Y. and Dahot M.U., 2010. Effect of various agricultural and pure sugars on the production of single cell protein by Penicilliumm expansum. Institute of Biotechnology and Genetic Engineering, 8: 80-84.

17. Kurbanoglu, E. B. and Algur, O.F., 2001. Production of single cell protein from Ram horn hydrolysate. Turkish. Bio, 25: 371-377.

18. Lenihan, P., Orozco, A., Neill,E. O., Ahmed M.N.M., Rooney, D.W., Walker, G.M., 2010. Dilute acid hydrolysis of lignocellulosic biomass. Chem. Engr. J., 156(2): 395-403. 
19. Mahasneh, I.A. (2005) Production of SCP from five strains of microalgae species. Biotechnol. Bioeng. J., 90: 153-161.

20. Nigam, N.M., 2000. Cultivation of Candida langeronii in sugarcane bagasse hemicellulose hydrolysate for the production of single cell protein. World.J.Microbiol. Biotechnol., 16: 367-372.

21. Piper, S. 2004. Continuos cultures of Methylococcus capsulatus. Center of Microbial Biotechnology (Biocentrum)- Technical University of Denmark, Master's thesis Saccharomyces cerevisiae, PhD. Thesis. Chalmers Univ. Techno, 90: 123-167.

22. Raja, R., Kumar, N.A., Sridhar, S. 2008. A perspective on biotechnological potential of microalgae. Cr. Revised Microbiol, 34: 77-78.

23. Sengupta, S., Bhowal, J., Bhattacharya, U. 2006. The Association of Official Analytical Chemists. The official methods of analysis of AOAC International, $18^{\text {th }}$ edn.J.Environ, Issues, Arlington, U.S. 6:99-126.

24. Tanveer, A. (2010). Production of single cell protein from Saccharomyces cerevisiae by utilizing fruit wastes. J. Environ. Issues, 1: 127-132.

25. Verma, S.V.S. and Sundar. G.S. (1988). Nutritive value of inactive dry yeast for broiler chicks. Ind. J. Anim, Nutr. 5: 137-143.

26. banana peels. Science world Journal: 3(4): 9-12.

27. Yousuf, M.K. (2012). To determine protein content of single cell protein produced by using various combinations of fruit wastes in the production of SCP by using two standard food fungi Aspergillus oryzae and Rhizopus oligospora Int. J. Adv. Biotechnol. Res. 3: 533-536.

28. Zubi, W. 2005. Production of single cell protein from base hydrolysed of date extract byproduct by the fungus Fusarium graminearum. M.Sc. Thesis, Garyounis University, Benghazi. 19: 167-225.

29. Zaho, C.H., Zhang, T., Chi, Z.M., CHI, Z., LI, . and Wang, X.H., 2010a. Single cell protein production from yacon extract using a highly thermosensitive and permeable mutant of the marine yeast Cryptococcus aureus G7a and its nutritive analysis. Bioproc. Biosy. Engin., 33:549-556. 